\title{
Castro’s Assassination Plot a Fiasco: A Study With Special Reference to Don DeLillo’s Libra
}

\author{
J. Kastrokumar, V. Gnanaprakasam \\ Annamalai University, Tamil Nadu, India
}

\begin{abstract}
DeLillo's treatments of Lee Harvey Oswald in Libra take place this rhetoric of image, and the place of image within historical, imagistic, and textual context. DeLillo's fiction is very much concerned with the ideological subtext of history that has exploited the resources of intertextuality. It has a long finding of meta-fiction to reveal there is no history without a full-blown meta-history to make plain Hayden White's contention. The general field of intertextuality was presented by Gerard Genette. Miami was a city of open wounds of explosive politics and feelings. Of all the cities, attempt made the conspiracy on the Cuban head. This city was very inflammable. Cuban heat and light were made him determined to keep the plan a secret from anti-Castro leaders. Four months earlier Kennedy had been accepted the brigade flag from survivors of the invasion, and many just have ransomed from Cuban prisons.
\end{abstract}

Keywords: intertextuality, conspiracy, Fidel Castro, John F. Kennedy

\section{Introduction}

Don DeLillo was born in the Bronx, New York on November 20, 1936. He received a bachelor's degree in communication arts from Fordham University in 1958. After graduation, he was a copywriter for an advertising company and wrote short stories on the side. He has won several awards for his fictions, including the National Book Award and the PEN/Saul Bellow Award. In the eerily convincing fictional portrait of President Kennedy's assassination, two Central Intelligence Agency (CIA) agents decide that America must be galvanized against Cuban dictator Castro's communism and the fake assassination attempt on the president's life of John F. Kennedy. Libra's protagonist of the novel, Lee Harvey Oswald, code name Libra, becomes the instrument in a conspiracy that goes terrifyingly awry.

In Libra, DeLillo (1988) compiled modern American history openly for the first time, drawing from the evidence, testimony, and analysis approached in the consequence of Kennedy's murder. The novel recreates the traumatic moment in Dallas, the "seven seconds that broke the back of the American century" (p. 181),

and offers, as the author's note appended to

the first edition puts it, "a way of thinking about the assassination without

being constrained by half-facts or overwhelmed by possibilities, by the tide of

speculation that widens with the years”. (p. 458)

J. Kastrokumar, Ph.D., research scholar, Department of English, Annamalai University, Tamil Nadu, India.

V. Gnanaprakasam, Dr., assistant professor, Department of English, Annamalai University, Tamil Nadu, India. 
This was the necessary cleansing of emotion (51). The Cuban dictator Fidel Castro plans to kill by Win Everett, who is the gun shooter and watches the every moment of his desire. The failure was openly acknowledged, 40,000 people were situated before in a football stadium. All the repressed materials sent into television land in reconverted waves, where Everett had watched. He respected the president for going to Miami. He was exclaimed and touched when the president's wife spoke Spanish members. The pure public administration made by the Kennedy's government, but the ceremony did not renew the forceful devotion to a free Havana. Everything ran with fear (52). The messenger Win Everett saw himself go inside a fellow on a quiet street doing, unafraid of being watched. Later, the president would venture out with his train of attendants, protectors, hand shakers and hacks, a city, and a street where he could be vulnerable. Everett was largely to wait a year for Miami. The message would be the clearest there; a difficult attempt made without the pointless human shot the target with handgun. He would consider the plan a success if the uncovering of successive layer.

DeLillo's crime fiction Libra reveals that the long narration of a president dies where Dealey Plaza, Texas on Friday, November 22, 1963 at 12.30 pm an unexpected shots ring out. Here, Kennedy's assassination is the fact of events, DeLilllo is the greatest thinker concentrating on the lives of Lee Harvey Oswald, some rogue former spooks unhappy with Kennedy's presidency. DeLillo's extraordinary Libra is a brilliant reimagining of the events and people surrounding the assassination of President John F. Kennedy. After the assassination, Nicholas Branch, a CIA architect is trying to make sense of or draw inferences from the mass of information. Libra presents an unapologetically provocative picture of America in the second half of the last century. Libra is a retelling of the assassination of John F. Kennedy by Lee Harvey Oswald.

Happiness is not based on oneself; it does not consist of a small home, of taking and getting. Happiness is taking part in the struggle, where there is no borderline between one's own personal world and the world in general (Lee Harvey Oswald letters to his brother, DeLillo, 1988, Part I).

Lee Harvey Oswald is the CIA's secret training base in Virginia. He was operated under military cover and used by agency people with short-term business at the base. The operation made by the American government under the guidance of John F. Kennedy activates the plan suggests that assassinate to Cuban dictator Fidel Castro. The farm was officially known by the cryptonym "isolation” (117). The names of places and operations were taken place in special language in the agency. Parmenter was interested in this language similarly found a deeper level, a secret level where those outside the cadre could not gain access to it. He is the junior officer trainees received instruction in everything from the paramilitary arts to the counterintelligence in the jot area. Win Everett, a secret serviceman, plans to kill Castro. He does not shoot anyone in the car that goes to 12 miles an hour. It is only five feet behind the presidential car, which makes it perfectly believable, an agent taking a bullet meant for the president.

Foreigners attending sessions at the farm were known as black trainees. A few of them on sensitive assignments had been brought to the U.S. under conditions so secure. The operation was extremely galvanizing the nation into full awareness of the danger of a communist Cuba. CIA Direction General de Intelligences would be exposed as a criminal organization that is willing to take extreme action against the important figures who opposed Fidel Castro. Shooting was in the works, designed to implicate the Director General of Intelligence. He wanted Frank and Raymo to be part of it and he supplied some operational details. The Cuban government helped arrange mineral surveys, land development deals, drilling contracts, and casino franchises. He traveled to oriental province to learn the extent of the rebel threat controlled by U.S. firms. After the 
revolution, the plan came to invade. He helped to set up the double-check corporation, a front for the recruitment of pilot instructors.

The assassination between the American President John F. Kennedy and the Cuban dictator Fidel Castro, and the great deal of incorporated business actually financed and controlled by CIA. During that time, several agencies helped to do something interesting in Kurdistan or Yemen conduct incorporation in Delaware. During this period, he came into contact with a number of agency assets that had important holdings in serious parts of the hemisphere. "A man from United Fruit, a man from the Cuban-Venezuelan Oil Trust" (it was George de Mohrenschildt as a matter of fact) (125). "Merchant banks, sugar companies, and arms dealers" (125). "A curious convergence of motives and holdings" (126). He saw a natural kinship between business and intelligence. The companies got the legitimate profits and beyond that enormous personal gain. Being rich, he saw, was something you grew into (126). Contact with wealthy and the influential nation of American genius for making leaps to new levels of privilege.

The agency had huge collections of intelligence on banana republic's and their leaders. The agency had spent time in Cuba and setting up transactions between the Batista government and interests in the U.S. government. The Cuban revolution was an armed revolt of Fidel Castro. It is allies against the authoritarian government of Cuban president Fulgenico Batista. This revolution began in July 1953, until the rebels finally ousted Batista on 31 December1958, replacing his government with a revolutionary socialist state. 26 July 1959, is declared in Cuba as the Day of the Revolution, later it called as the 26th of July movement. From the movement, the CIA had monitored a repel plan broadcast on 1 January 1959 announcing that the tyrant Batista had run away the country at 2:00 am and that Dr. Fidel Castro Ruiz was the supreme leader of the Cuban revolution from that moment. It is the struggle hanging over the life that made him go away (133). New Orleans is the assignment to kill the enemy camp. Before the murder, attempt comes the provocation (138).

The story was fabricated yet the plan itself was real, associating the assassination of Fidel Castro and his brother Raul. This news could be found among the subject's effects after the failed attempt on the life of the president. Once people saw the attempt on the president as a Cuban response to repeated efforts of U.S. intelligence agency to murder Castro, all those U.S. firms could fight for Castro and then crossed over. They got the dark rage in every face. Fidel Castro betrays the revolution. American President John F. Kennedy had made his deal with the soviets to leave Castro alone. Knowledge was a danger; ignorance is a cherished asset (21). Several plans had made to murder anti-crusader Castro by the DCI (Director of Central Intelligence), who is all the attempts met with failure.

\section{Conclusion}

DCI would impair his ability to tell the truth at an inquiry or a hearing mode in an oval office chat with the president, even they were muttering on his sleep. The joint chiefs were not to know. The operation horrors were not for their ears. Collecting details was a form of contamination. The secretaries were to be insulated. Each level of the committee was designed to protect a higher level. They were planning to kill through poison Castro cigars. They were designing cigars contained with micro explosives. They had a poison pen in the works. They were conspiring with organized crime figures to send assassins to Havana, poisoners, snipers, saboteurs. They were tested a botulin toxin on monkeys. Fidel would be seized by cramps, vomiting, and fits of coughing, just like the long-tailed primates, and horribly die. Besides, it is estimated that the CIA attempted to assassinate Castro 638 times while he was president of Cuba. 


\section{References}

DeLillo, D. (1988). Libra. New York: Penguin Group.

DeLillo, D. (1983). American blood: A Journey through the Labyrinth of Dallas and JFK. New York: Rolling Stone.

Kastrokumar, J., \& Gnanaprakasam, V. (2018). Don DeLillo: A postmodernist. Riga Latvia, European Union: Just Fiction Edition. Lentricchia, F. (Ed.). (1991). Libra as postmodern critique. In Introducing Don DeLillo (p. 195). Durham: Duke University Press. 